\title{
The Empowerment Model for the Poor Based on Spiritual Skills and Life Skills in Productive Age of the Youth at Rumah Gemilang Indonesia
}

\author{
Kholidhidayatullah ${ }^{1, *}$, Bahri Ghazali ${ }^{2}$, Shonhaji ${ }^{2}$, Rosidi ${ }^{2}$, Ahmad Hadi \\ Setiawan $^{3}$, Muhamad Rudi Wijaya ${ }^{4}$, Khoirurroji'in ${ }^{5}$ \\ ${ }^{1}$ Faculty of Islamic Religion, Muhammadiyah University of Pringsewu Lampung Indonesia \\ ${ }^{2}$ Department of Dakwah, UIN Raden Intan Lampung, Indonesia. \\ ${ }^{3}$ Department of Education, Faculty of Education Arabic, STIT Darul Fattah Lampung, Indonesia. \\ ${ }^{4}$ Departmen of Syariah Economic Law, STIS Darul 'Ulum Lampung Timur, Lampung, Indonesia. \\ ${ }^{5}$ Department of Syariah, IAI Agus Salim Metro, Lampung, Indonesia \\ *Corresponding author email: kholidhidayat.kh@gmail.com, rudiwijaya68@gmail.com
}

\begin{abstract}
Rumah Gemilang Indonesia is a community institution that focuses on empowering youth of productive age. This study aims to describe the empowerment model of productive age youth at Rumah Gemilang Indonesia LAZ AL-Azhar. This research was studied qualitatively through a descriptive approach. The method of data collection is done by interview, observation, and documentation. Data analysis used interactive analysis model of Miles and Huberman. The model of empowering the poor through the Productive Youth empowerment program built in this study refers to the program evaluation model framework developed by Kaufman and Thomas (1980). This model was chosen because it places more emphasis on a system, namely an empowerment system that includes inputs, processes, outputs and outcomes. The results showed that youth empowerment that combines life skills with spiritual skills can be an effective model to reduce poverty. In conclusion, the empowerment model compiled by RGI LAZ Al-Azhar uses an approach that combines the concept of a work training center in the form of a short course with a boarding school platform. So that in its implementation the material taught in the Empowerment Process through two approaches, namely life skills and spiritual skills. The process of empowering youth through life skills in poor families is carried out by RGI through three stages, namely: 1 . awareness process, 2 . transformation process 3. process of increasing intellectual abilities and skill proficiency. The process of youth empowerment through spiritual skills in poor families is carried out by RGI through 3 stages, namely: 1 awareness through self and character surgery activities 2. Implementation of spiritual care community programs through daily worship routines, weekly activities, monthly activities. 3. Evaluation
\end{abstract}

Keywords: Models, Life Skills, Rumah Gemilang

\section{INTRODUCTION}

The empowerment of young age groups must be a priority for the nation. as an effort to optimize the contribution of young people to sustainable development and national resilience. the younger generation are the current and future actors. The success of our population development depends on how we invest in them and involve them optimally for their future, their communities and the nation.

Based on future projections, in 2020-2030 Indonesia has the opportunity to enjoy the window of opportunity as a blessing from the demographic bonus, provided that it is supported by qualified and high capacity productive age human resources. Youth development and empowerment has a central role in realizing the window of opportunity, namely by preparing young people with quality and capacity. However, until now, Indonesian youth are still faced with very complex problems. Some of them are still illiterate, have low education levels and do not have access to jobs. Some of them are involved in drug abuse, promiscuity and are involved in various crimes and various other social problems. On the other hand, several incidents of violence such as anarchist demonstrations or brawls between students have tarnished the faces of the student and youth movements. Many people feel disappointed and antipathy with the student-youth movement pattern which tends to be anarchic and disturbs the public interest. On the other hand, youth activists have been subordinated by other forces so that young people cannot actualize their potential and identity.

According to data released by the United Nations (UN), the number of young people in the world has currently reached 1 billion, and $85 \%$ are in developing countries. About $60 \%$ of them are located in Asia, including Indonesia, and $15 \%$ in 
Africa with high poverty rates and lack of decent work opportunities. The International Labor Organization (ILO) estimates that globally there are 88.2 million youth unemployed or $47 \%$ of the world's 186 million unemployed [1].

Youths who will later become national leaders in the future must be well prepared and mature so that the role of youth should be revitalized from an early age, because leadership requires integrity, capacity, experience and emotional maturity. The end of all that is wisdom and policy. The crucial thing in the problem is how a young leader is able to make wise decisions quickly and correctly that have an impact on the progress and welfare of the people in nation building.

Edi Suhartos in Ahmad Rifa'i defines empowerment derived from the word "power" (power or empowerment). Therefore, empowerment aims to increase the power of the weak or disadvantaged. In this case, how can the less empowered and less fortunate people be empowered and empowered to help themselves [2]. Then according to Jim Ife in Ahmad Rifa'i, "empowerment means preparing to the community the resources, opportunities, knowledge, and expertise to increase the expertise of the community and influence life in the community itself. Meanwhile, according to Manuwuto, community empowerment is an effort enhances the dignity of the strata of society whose condition at one time was unable or unable to escape the trap of poverty and underdevelopment. In other words, empowerment is an effort to make a community group capable and independent

Agus Efendi said that when viewed from three areas that are important to be empowered, there are at least three areas of empowerment activities that are urgent to be fought for, namely spiritual empowerment, intellectual empowerment, economic empowerment [3]. first, Empowerment of spiritual elements. The spiritual side is a very basic empowerment area, because there is a lot of moral degradation, especially for the younger generation who are undermined by western habits that do not reflect Islamic values. So to get out of this condition, it is necessary to do a review of the educational curriculum that is not oriented in the context of empowerment and does not conflict with scientific truth. Second, intellectual empowerment. Intellectual means intelligent, intelligent, and think clearly based on science. Empowerment in this field is no less important than spiritual empowerment. This is done in order to catch up in the field of science and technology. Empowerment of this type, it is important to be developed as an effort to combat self-ignorance and also to teach what has been learned to society in general both through education. Third, economic empowerment. The problem of poverty is one of the problems that often occurs in society. And it becomes a shared responsibility in society. To get out of this economic problem, a big struggle is needed by every component of society. By building a work ethic that is more communicative, persistent, and creative, and entrepreneurial, in interactions; more and more professional in managing the economic potential of the people.

Currently, the youth empowerment process focuses more on the aspect of knowledge (transformation of knowledge), or in other words our education emphasizes the life skills aspect, less emphasis on spiritual skills. Spituall skills are nontechnical abilities that are not visible but are indispensable for success and non-technical abilities that help someone to develop themselves completely to apply positive values, and are facilities that help someone to overcome problems and make peace with their problems. The development of youth human resources through a combination of lifeskills and spiritual skills is the main solution to the problem of developing youth empowerment strategies in poor communities.

\section{METHODS}

This study uses descriptive qualitative methods, namely research procedures that produce descriptive data about objects in the form of written or spoken words from people and observed behavior in order to obtain the data needed [4]. Based on the case, this research is related to the problem of youth empowerment model based on life skill and spiritual skill in RGI LAZNAS AL-Azhar. There are several reasons to consider in choosing the location of Rumah Gemilang in this study, first, the AL-Azhar Zakat Institute through Rumah Gemilang Indonesia has implemented a very successful community empowerment program. Second, LAZ Al-Azhar's achievement as the winner of the best utilization program category award and the best annual report in the awarding of the 2018 National Zakat Award (Baznas). Rumah Gemilang Indonesia is a charity organization that specifically creates and organizes youth empowerment programs that do not exist in other institutions. Data sources in this study are divided into two, namely primary data sources and secondary data sources. The primary data sources are the house managers Gemilang Indonesia and LAZNAS Al-Azhar. Meanwhile, secondary data comes from books, magazines, BPS data, and other 
sources that support research (as subjects, respondents and data sources). To obtain data in this study, researchers used three techniques (methods), namely observation, interviews and documentary studies related to the empowerment of productive youth.

\section{RESULTS AND DISCUSSION}

Empowerment Patterns of youth of productive age in Rumah Gemilang Indonesia combines the concept of a work training center in the form of a short course with a boarding school platform. Like a pesantren, every training student is required to live in a dormitory. The goal is that religious content can be absorbed optimally. Because the guidance of worship in daily routines must be carried out by participants of Rumah Gemilang Indonesia in a series of Spiritual care Community programs. This combination is intended so that the RGI training participants not only absorb superior knowledge and skills that become the foundation for their future, but also have the knowledge and foundation of good faith beliefs. In simple terms, the model building run by RGI in carrying out its empowerment program can be shown as follows:

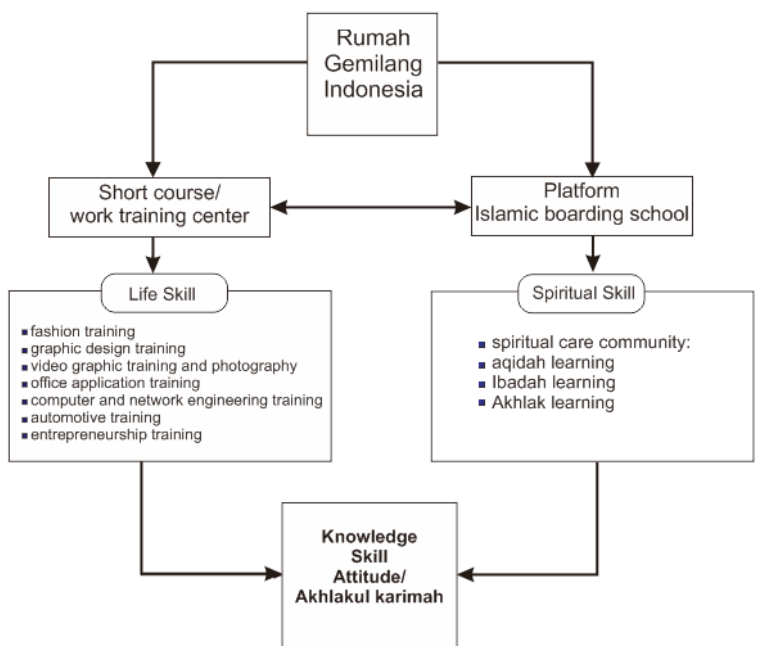

FIGURE. 1 Youth empowerment patterns at RGI

\subsection{Productive Youth Empowerment Process through life skill training}

If viewed from the empowerment process theory advanced by Sulistiyani, that the empowerment process is done through a process circuit which is [5] : 1. the process of awareness, 2. process pentransformasian intekektual 3. the process of upgrading skills and proficiency. So this has been done by the Rumah Gemilang Indonesia in the skill- based empowerment process for youth of productive age. The series of processes that exist in Rumah Gemilang Indonesia can be explained as follows:

\subsubsection{Awareness process.}

The basic principle is to make targets understand that they need to be empowered and the empowerment process starts from within them to foster a conative attitude (attitude to grow and learn). The touch of leaning will further open the desire and awareness of the public about his current condition, so that it will stimulate awareness about the need to improve conditions to create a better future. Thus the community is more open and feels they need knowledge and skills to improve conditions.

Empowerment can also be called a process of developing thought patterns and attitudes that encourage public awareness to want to improve their lives by developing their potential. Awareness efforts carried out by the Rumah Gemilang Indonesia with self-improvement and character activities which are still included in the series of motivational studies which the Rumah Gemilang Indonesia calls the spiritual care community program. One of the materials in the program is motivation training. The participants were always enlightened that every human being has the opportunity to become a successful person. Humans can change and must continue to change, there are many opportunities for success in the present and future that must be prepared to be able to achieve it. Success is not only seen from the material side but also from the spiritual side. Why be successful if he does not have faith. Motivation is continuously carried out so that it is hoped that they will raise their awareness of the motivation to improve the situation that is better than before. As stated by Wikirannolo and Riant Nugroho Dwidjowijoto, part of the awareness stage is to provide understanding regarding the right to become capable and motivate them to get out of the shackles of poverty and the shackles of helplessness [6].

\subsubsection{The transformation process.}

The transformation Process is often defined as the process of transformation of knowledge and skills, namely an effort to transfer knowledge, skills, management and values that can be used as a reference towards independence. This situation will stimulate open insight and master the basic skills they need.

Efforts made in the transformation of skills by Rumah Gemilang Indonesia are by providing skill training in the form of: 1. Graphic Design Training Class 2. Computer Network Technique Training 
Class (TKJ). 3. Dressmaking Class 4. Office Application Training Class 5. Photography and Videography Class 6 . Automotive training class. The selection of the ski field as the material taught by Rumah Gemilang Indonesia is considered very appropriate. This can be seen in the current labor market needs for these skills. The hope is that after gaining skills and knowledge in these areas of expertise, participants can immediately be absorbed in the job market. Of the several alumni that researchers interviewed after the apprenticeship process was completed, they were immediately asked to work at the place where they had previously interned. This is in accordance with what parsons said that " Empowerment emphasizes that, people acquire, skills, knowledge and power sufficient to influence their lives and the lives of others who concern them" [7].

Another material provided by Rumah Gemilang Indonesia in skill empowerment is entrepreneurship training. As a provision of knowledge and experience when later they are involved in the community and have direct contact with the business world, the empowerment participants after participating in the training process are given material on leadership and entrepreneurship. The materials mentioned above are used as a reference for Rumah Gemilang Indonesia when implementing its empowerment model. Preparations made will be very in touch with how existing human resources are improved quality by providing a variety of life skills (life skills) and adding entrepreneurial insight. Become an entrepreneur (Entrepreneur) who is educated and trained in facing challenges and able to find existing business opportunities is a profitable alternative for students to apply in real life.

For the Rumah Gemilang Indonesia (RGI) Entrepreneurship is a strong belief that there is in a person to change the world through ideas and innovation. This belief is then followed up with the courage to take risks to realize these ideas and innovations through the organization that was founded, starting from building, maintaining, developing, to producing a real impact on the world. People who have this belief are called entrepreneurs or entrepreneurs. Becoming an entrepreneur is one step to achieve success. Realizing this, RGI conducts entrepreneurship or intrepeneur training, especially for alumni to become entrepreneurs when they graduate. Associated with the empowerment theory presented by Mardikanto (2010), the material for leadership and entrepreneurship chosen by Rumah Gemilang is quite meaningful, because it has chosen the most important material in empowerment, namely material related to the direction of economic strengthening or business development. Economic strengthening is the most important empowerment material, because any strengthening without having an impact or benefit on improving welfare will only add to disappointment [8].

\subsubsection{The process of increasing intellectual abilities and skills proficiency.}

This third process is the stage of empowering or increasing intellectuality and the necessary skills, so that they can form their independence abilities. This stage seeks to provide authority, opportunity, and trust to individuals or communities to develop according to their creativity. This independence will be marked by the community's ability to form initiatives.

After students have skills, it is necessary for them to be empowered so that they can be empowered. This means that one day they will be able to make themselves independent or even prosperous. The provision of power does not have to be in the form of financial assistance, but also requires assistance with access to employment or entrepreneurship. What has been done by RGI, for example, is to provide access to internships at partner companies, agencies and institutions. Apprenticeship is needed to gain experience and apply the theory that has been taught as well as to develop the knowledge and skills of the participants when they are in the world of work and also build networks for training participants. One of the objectives of the apprenticeship is also because it considers that most of the education and training students do not have a proper diploma as a standard requirement for applying for jobs in the formal field. There are even those who do not have any diplomas, many of the factors causing it are those who have never graduated from school. There are also those whose diplomas cannot be obtained from school because of unpaid tuition fees. Therefore, RGI builds partnerships with companies and business units that can receive skilled and good morals without requiring a certain diploma. However, RGI does not always guide all training students to become employees. RGI is more motivating and directing the alumni to be independent by doing entrepreneurship, motivating them to build their own jobs to become entrepreneurs so that they can create jobs for others. The apprenticeship program will be implemented within one month after completing the regular program, namely training and workshops.

Apart from apprenticeship there are also factory tour activities. Like the TKJ class RGI students have made visits and comparative studies at the Anabatic 
Technology company in Jakarta. A company engaged in IT "Information Technology" and focus in software development activities in collaboration with companies international for example, Microsoft, IBM, Cisco, and so on. This factory tour activity is expected to increase knowledge and expertise in the field of information technology development is quite fast, thus increasing enthusiasm and new motivation to TKJ students to work hard, diligently and earnestly in studying at Rumah Gemilang Indonesia.

\subsubsection{The results of empowering life skills.}

When viewed from the purpose of empowerment, the youth empowerment program of productive age in poor families has the aim of:

a. Better Institution, which aims to improve institutions, develop business partnership networks. In this case, it is a household institution that has youth, namely in the family compensation program. b) Better BusinessBusiness (Improvement), which aims to improve the business being carried out

b. Better Income, which aims to improve the income earned.

c. Better Living, which aims to improve the living conditions of every poor family of youth

d. Better Community, which aims to create a better society.

\subsection{Productive Youth Empowerment Process through Spiritual skill activities}

Based on the research findings, the empowerment in the spiritual dimension carried out by Rumah Gemilang Indonesia is in the context of realizing the vision of Rumah Gemilang Indonesia. As explained in the previous chapter that one of the visions of Rumah Gemilang Indonesia is

"To become a center for education and skills training as well as community development capable of creating a creative, productive, independent and noble generation."

Noble or good morals are a reflection of correct aqidah and true worship. So that in order to create human beings with noble character, Rumah Gemilang undertakes spiritual empowerment efforts through material related to tauhid, fiqh (religious practice) and akhlak. So that later RGI students are expected not only to be equipped with certain skills, but also to be equipped with an understanding of religious values so that they have a good mental attitude, personality and character and when they enter the community they are able to become agents of change for their family and environment.

The selection of spiritual material as an empowerment program material carried out by the Rumah Gemilang Indonesia to support empowerment in life skills is very appropriate as confirmed by what was conveyed by Nanih Machendrawaty and Agus Ahmad Syafe'i. That there are three dimensions or areas of empowerment that must be fought in the context of the present peoplehood is the level of spiritual empowerment, intlektual, and the economy [9].

a. Empowerment in the spiritual field.

Agus Efendi argues, the shift in values or moral degradation of the Islamic community today, especially the majority of the young generation is so naked that it is co-opted by western culture which tends to be negative and inconsistent and even contrary to Islamic values. Religious education, formal educational institutions on various fronts are unable to instill divine values in their students.

b. Empowerment of intellectual fields.

Allegedly, Muslims are not isolated in Indonesia experiencing stagnation in the mastery of science and technology that relies on faith and piety. For this reason, intellectual empowerment is very urgent to be fought for.

c. Empowerment in the economic sector.

The population is so large and the majority are Muslim, so the large number of people who are shackled in poverty are Muslims. Various government efforts to reduce poverty have not shown significant results. For this reason, policies that are more pro-poor and marginalized are needed.

As seen by Ife, spiritual development is very important in supporting the meaning of human life. Spiritual filling human inner emptiness and give meaning to human identity. Ife further emphasized, "The spiritual dimension is very important for community development. A sense of sacredness and respect for spiritual values is an important part of the reconstruction of human society and gives meaning and purpose to human life. the conclusion is that spirituality is important in human growth and development, both as individuals and collectively. This is what will color human activities related to the 
value of an activity.

Based on the findings of the study, the empowerment process in the spiritual dimension carried out by Rumah Gemilang Indonesia through spiritual activities in the form of daily, weekly and monthly activities through Spiritual Care Community ( $S C C$ ). Every training participant from various study programs receives mandatory material in the form of a Spiritual Care Community (SCC). $\mathrm{SCC}$ is a motivation and character building program for participants. All participants also receive special spiritual assistance provided by the accompanying instructor. In an effort to strengthen mentally and spiritually and develop morality, all training participants are required to follow this material. There are two main instructors for the Spiritual Care Community (SCC) program at Rumah Gemilang Indonesia, namely Ustadz Kamaludin and Ustadz Salman Al-Farisi. There is a Spiritual Care Community (SCC) program in the form of daily, weekly and monthly activities. For daily activities that are routinely carried out are:

a. Midnight prayer and muhasabah

b. Prayers in congregation 5 times a day

c. Tadarus Al-Qur'an

d. Read surah al-Waqiah

e. Memorizing surah al-Quran chap 30

f. Duha prayer together

g. Mental Surgery and Character Building

h. study of tauhid and fiqh

i. ta'lim after Dhuhr prayer

j. ta'lim after Asr prayer

The activities that are weekly are:

a. Dawn in congregation of male and female students

b. Study of Tafseer and Hadith

c. Mutual help in cleaning the dormitories and doing sports

The activities that are monthly are the following:

a. Mabit (Night of Faith and Taqwa)

The SCC coach is also always ready and provides special time for assisted students who want to consult and find solutions to any existing problems, both family and personal problems and even other social problems.

\subsection{The results of empowering life skills and spiritual skills}

Clarity of concepts and a set of empowerment inputs supported by a neat empowerment implementation process actually has an impact on outputs and outcomes. The output generated from the implementation of empowerment through life skill activities and the spiritual care community includes four things, namely strengthening character, increasing the economy, strengthening emotional ties, and strengthening institutions.

\subsection{1. $\quad$ Strengthening human character or development.}

Strengthening character is the result achieved from efforts to raise spiritual awareness, awareness of entrepreneurial leadership, and provision of capacity building carried out by RGI or its partner institutions. The results of character strengthening are marked by the formation of young people who have skills, are knowledgeable and have a character who likes to worship and has good morals. The impact is the formation of prospective workers and entrepreneurs who are honest, trustworthy and have good character because they are supported through upbringing and religious values that are used as a guide for their lives. As stated by Mardikanto, human development includes the development of individual, institutional and system capacities.

\subsubsection{Economic strengthening or} business development.

Business development or economic strengthening is an effort where there must be "urgency" in every empowerment. Because empowerment that does not produce or give a beneficial impact on improving life expectancy can increase disappointment for the empowered community. The results of the strengthening of the economy have been marked and some have become entrepreneurs, thus opening up new jobs. The new job opportunities are expected to have an impact on empowered communities in the form of independence or even welfare.

\subsubsection{Strengthening emotional ties or building the environment.}

Strengthening emotional ties is the result of entrepreneurial awareness efforts and capacity building carried out by the RGI Institute or fellow students and alumni of RGI, as has been done by Marino. As stated above, Marino, an RGI alumnus who has become a young entrepreneur with a turnover of hundreds of millions, has built entrepreneurial awareness for his fellow RGI family friends. He also did not forget to always provide motivation and share life experiences with other RGI students and alumni. The results of his efforts include the development of a work environment that supports his efforts, namely building business cooperation between RGI students and himself. This is in accordance with Mardikanto's statement that 
environmental development greatly affects business sustainability.

\subsubsection{Institutional strengthening or institutional development.}

Institutional strengthening is the result achieved by LAZ Al-Azhar in building networks, both internal and external networks. The results of institutional strengthening are marked by the formation of cooperation with other institutions, LAZ Al Azhar is an agency that is engaged in a charity program, so that in order to support its operational activities it is highly dependent on fundraising activities "fundraising". Fundraising activities carried out by LAZ Al Azhar are in order to support programs so that they can run according to planning and end well. To maximize the process and output, RGI continues to build partnerships with various parties:

a. Synergize with generous donors, donor agencies, partnerships with CSR, to support operational activities and provide training tools.

b. Synergize and build partnerships with government private institutions such as industrial bodies or create networks with business units for apprenticeship programs, factory tours and job market information

c. Build partnerships with BAZ, LAZ, and agencies or institutions in the regions

d. Synergize with civil society in the process of recruiting training participants throughout Indonesia.

Therefore, Mardikanto stated that with good institutional development it is hoped that the business partnership network will run smoothly. Meanwhile, the outcome for empowerment is the empowerment of RGI students.

This empowerment is marked by the formation of youth as workers or entrepreneurs with honest, trustworthy and noble characters based on strong religious practice, the realization of congregational independence / welfare which is marked by the existence of new zakat (muzzaki), business continuity can also be built due to the wide network tied up with other parties. as well as the availability / ease of access to capital for business development due to the large number of collaborations with other institutions

\section{CONCLUSION}

Community empowerment includes very broad aspects, both economic, social, cultural, political and even spiritual. Community empowerment is an effort to improve community welfare. Community empowerment efforts to face various problems and challenges, it is necessary to make strategic efforts to develop community empowerment. The empowerment model for youth of productive age in Rumah Gemilang Indonesia LAZNAS AL-Azhar combines the concept of a work training center in the form of a short course with a boarding school platform. Based on the above study, a youth empowerment model for the poor that combines life skills with spiritual skills can be an effective model for reducing poverty.

\section{REFERENCES}

[1] Ersas A. Gahung, Peran Pemerintah dalam Pemberdayaan Pemuda di desa Liwutung Kecamatan pasan kabupaten minahasa tenggar, (Manado: Universitas Samratulangi Manado, 2018), pp. 5

[2] Ahmad Rifa'i, Mosque-Based Community Empowerment Case Study at Masjid AlIkhlash Jatipadang Pasar Minggu, South Jakarta, (Jakarta: UIN Syarif Hidayatullah Jakarta, 2014).pp. 86

[3] Nanih Machendrawatyy dan Agus Ahmad Safeii, Pengembangann Masyarakat Islam dari Ideologi Strategi sampai Tradisii ( Bandung: Rosda Karya, 2001), pp. 44.

[4] Sudarto, Metodologi Penelitian Kualitatif, (Jakarta: PT. Raja Grafindo Persada, 2002), cet-3, pp. 62.

[5] Wrihatnolo, R.R. and Dwijowijoto,R. N. Empowerment Management, An Introduction and Guide to Community Empowerment, (Jakarta: PT.Elex Media Komputindo 2007), pp. 101

[6] M. Anwas. Pemerdayaan Masyarakat di Era Global. (Alfabeta, Bandung, 2014). pp.49.

[7] Mardikanto, Pemberdayaan Masyarakat dalam persepketif kebijakan publik, Bandung: Alfabeta 2017), pp. 67.

[8] Nanih Machendrawatyy, dan, Agus Ahmad Safeii, Pengembangann Masyarakat Islam dari Ideologi Strategi sampai Tradisii (Bandung: Rosda Karya, 2001), pp. 65.

[9] Kahmad Dadang. ), Sosiologi Agama, Bandung: PT Remaja Rosdakarya, 2002.), pp. 44 